J Forensic Sci, July 2007, Vol. 52, No. 4 doi: $10.1111 /$ j.1556-4029.2007.00486.x Available online at: www.blackwell-synergy.com

Carme Rissech, ${ }^{1,2}$ Ph.D.; George F. Estabrook, ${ }^{3}$ Ph.D.; Eugenia Cunha, ${ }^{1}$ Ph.D.; and Assumpció Malgosa, ${ }^{2}$ Ph.D.

\title{
Estimation of Age-at-Death for Adult Males Using the Acetabulum, Applied to Four Western European Populations*
}

\begin{abstract}
Methods to estimate adult age from observations of skeletal elements are not very accurate and motivate the development of better methods. In this article, we test recently published method based on the acetabulum and Bayesian inference, developed using Coimbra collection (Portugal). In this study, to evaluate its utility in other populations, this methodology was applied to 394 specimens from four different documented Western European collections. Four strategies of analysis to estimate age were outlined: (a) each series separately; (b) on Lisbon collection, taken as a reference Coimbra collection; (c) on Barcelona collection, taken as a reference both Portuguese collections; and (d) on London collection taken as reference the three Iberian collections combined. Results indicate that estimates are accurate (83-100\%). As might be expected, the least accurate estimates were obtained when the most distant collection was used as a reference. Observations of the fused acetabulum can be used to make accurate estimates of age for adults of any age, with less accurate estimates when a more distant reference collection is used.
\end{abstract}

KEYWORDS: forensic science, adult age estimation, acetabulum, Bayesian inference, aging, human identification

Although methods to estimate age-at-death for children and adolescents are fairly accurate, those for adults remain less reliable (14). Problems include: (a) low accuracy in the age estimation of specimens that lived beyond 60 years of age (5-7); (b) the tendency to estimate most ages-at-death between 30 and 50 years old; (c) occasional very inaccurate estimates; and (d) the tendency of estimates to reflect the age-at-death structure of the reference collection $(7,8)$. These problems are exacerbated by the variability of the aging process both within and between populations $(9,10)$ and by the scant knowledge of the relationship between various pathologies and the aging process itself (11). For these reasons it is necessary to improve the objectivity and accuracy of available methods and to develop new ones.

Since the publication of Lucy (12) and the Rostock Manifesto (13), there has been a growing interest in developing new methods. Some new approaches include: probability models $(7,9,10,14,15)$; more accurate definition of what and how to measure $(7,9)$; analyses of the influence and relationship between some pathologies and indicators of age (11); analysis of how the aging process varies within populations $(10,16)$; and the proposal of new indicators of age. In this way, there have recently appeared several studies of the acetabulum that demonstrate its utility as a basis for estimating age-at-death by making relatively more accurate

\footnotetext{
${ }^{1}$ Departmento de Antropologia, Facultade de Ciências, Universidade de Coimbra, 3000-056 Coimbra, Portugal.

${ }^{2}$ Unitat d'Antropologia, Department de Biologia Animal, Vegetal i Ecologia, Universitat Autònoma de Barcelona, 08193-Bellaterra, Spain.

${ }^{3}$ Department of Ecology and Evolution, University of Michigan, Ann Arbor, MI

*Part of this work was presented as a communication in the VIII Congress. de la Sociedad Española de Paleopatologia. $1^{\text {er }}$ Encuentro HipanoLuso de Paleopatologia in Cáceres, Spain (16-19 November, 2005). The title of the communication was "Estimación de la edad adulta masculina a través del acetábulo. Aplicación en una muestra de Europa occidental."

Received 14 Sept. 2006; and in revised form 24 Feb. 2007; accepted 24 Feb. 2007; published 4 June 2007.
}

estimates of age-at-death when applied to adult males in the collection: Esqueletos Identificados in the Anthropology Museum of the University of Coimbra, Portugal $(17,18)$. In these studies, seven new acetabular variables were described and age-at-death was estimated within 10 years of known age-at-death for $89 \%$ of the specimens, using the Bayesian estimation technique described by Lucy et al. (12). The purpose of the work reported here is to evaluate these variables and this technique in other collections of human skeletal remains and to compare its accuracy when collections representing different geographical regions are used as reference collections.

\section{Materials and Methods}

The osteological materials come from four collections of human skeletal remains from Western Europe in which each specimen's sex, age-at-death and biological origin was known: Esqueletos Identificados of Coimbra (19th and 20th centuries) housed in the Anthropology Museum of the University of Coimbra, Coimbra (Portugal) (19); Lisbon collection (19th and 20th centuries) housed in Museo Bocage, Lisbon (Portugal) (20); UAB collection (20th century) housed in the University Autonònoma Barcelona, Belleterra (Barcelona, Spain) (21,22); and St. Bride collection (18th and 19th centuries) housed in St. Bride's Church, London (U.K.) $(23,24)$. Male individuals with fused acetabulum were chosen for this study. We excluded individuals who showed pathologies affecting the acetabulum but did not exclude those with non-inflammatory osteoarthritis or diffuse idiopathic skeletal hyperostosis (DISH), which are themselves indicators of aging $(9,25)$. By these criteria, 394 specimens between 15 and 96 years of age-at-death were analyzed: 242 from Coimbra, 57 from Lisbon; 18 from Barcelona; and 77 from London. Results reported here are based on measurements taken from the left side only. All observations were made by the first author.

The wide range in ages enabled us to examine a broad spectrum of the morphological variation of the fused acetabulum through the 
human life span. The variables measured are described and evaluated extensively by Rissech et al. (18); only minimal intra- and inter-observer variability was detected. The seven variables are: (a) acetabular groove, (b) acetabular rim shape, (c) acetabular rim porosity, (d) apex activity of the posterior extremity of the lunate surface, (e) activity on the outer edge of the acetabular fossa, (f) activity of the acetabular fossa, and $(\mathrm{g})$ porosities of the acetabular fossa. Upon observation, a specimen is described by placing it into one of several descriptive states for each variable. Estimates of the age-at-death for a test specimen were calculated using frequencies in a reference collection and the Bayesian inference technique used by Rissech et al. (18) and described by Lucy et al. (12). In applying these methods here, the a priori probability of any 5-year age-at-death class was taken to be the fraction of individuals in the reference collection in that age-at-death class. Each individual whose age-at-death was estimated is presumed to be a sample of the population represented by the reference collection. An estimate of age-at-death takes the form of a probability distribution over 5-year wide age-at-death classes: 15-19, 20-24, etc. A single year estimate of age-at-death was calculated as the expected value of this distribution, attributing to each age class its central age.

To carry out our analysis, age-at-death was estimated in four different ways using different collections for test and reference:

1. We estimated the age-at-death for each specimen in each collection using the rest of the collection from which the test specimen was drawn as the reference collection to calculate estimating frequencies (Jacknife resampling strategy [26]).

2. We estimated the age-at-death for each specimen from Lisbon collection using Coimbra collection as the reference collection.

3. We estimated the age-at-death for each specimen from the $\mathrm{UAB}$ collection using the combined Portuguese collections as the reference collection.

4. We estimated the age-at-death for each specimen from St. Bride collection using the combined Iberian collections as reference.

\section{Results}

We used the expected value of the calculated distribution of ageat-death as an estimate of the year of death, and expressed our results as the difference between estimated and known age-at-death for each specimen in each of our seven analyses. They are summarized in Table 1 and presented explicitly in Figs 1-7. In these figures, each specimen is represented by a bar over its known ageat-death. This bar extends up (overestimate) or down (underestimate) from 0 to indicate the difference between the known and estimated ages-at-death for each specimen in the leftmost collection named above the figure, when the rightmost named collection is used as reference.

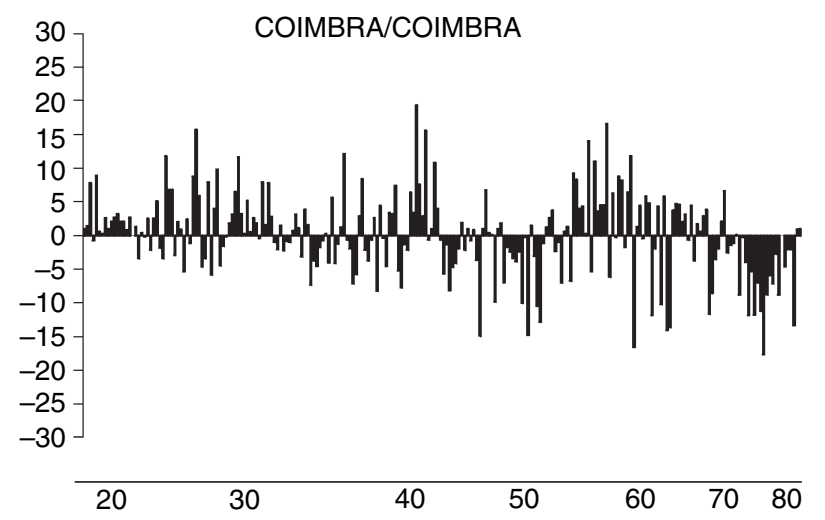

FIG. 1-Difference between the known and estimated ages-at-death for each specimen in the Coimbra collection, when the same collection is used as reference.

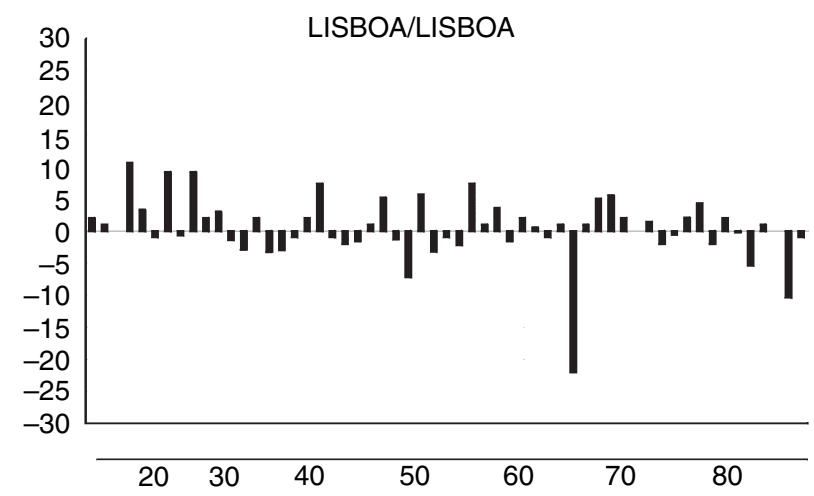

FIG. 2-Difference between the known and estimated ages-at-death for each specimen in the Lisbon collection, when the same collection is used as reference. See the text.

Within collections at Coimbra, Lisbon, Barcelona and London differences of at most 5 years occurred for $67 \%, 75 \%, 94 \%$, and $69 \%$ of the specimens respectively; within 10 years the respective percentages were $89 \%, 95 \%, 100 \%$, and $83 \%$.

When ages-at-death for Lisbon specimens were estimated using specimens from Coimbra as reference, $43 \%$ were within 5 years of the known age-at-death, $78 \%$ within 10 years, and $87 \%$ within 15 years.

When ages-at-death for Barcelona specimens were estimated using specimens from Coimbra and Lisbon as reference, $56 \%$ were within 5 years of the known age-at-death, $78 \%$ within 10 years, and $94 \%$ within 15 years. Worst results were obtained when ages-atdeath for London specimens were estimated using specimens from

TABLE 1-Percentage of individuals in the leftmost collection labeling the rows, whose estimated age-at-death differs from known age-at-death by less than the amount labeling the columns, when rightmost collection labeling the rows is used as a reference collection.

\begin{tabular}{lccccc}
\hline & No estimate & $<2$ years $(\%)$ & $<5$ years $(\%)$ & $<10$ years $(\%)$ & $<15$ years $(\%)$ \\
\hline Coimbra/Coimbra & 4 & 33 & 67 & 89 & 97.5 \\
Lisbon/Lisbon & 0 & 40 & 75 & 95 & 98.25 \\
UAB/UAB & 0 & 50 & 94 & 100 & 100 \\
St. Bride/St. Bride & 0 & 11 & 69 & 83 & 98.25 \\
Lisbon/Coimbra & 3 & 11 & 41 & 78 & 90 \\
UAB/Portugal & 0 & 10 & 30 & 78 & 97 \\
St. Bride/Iberia & 1 & & 56 & 94 \\
\hline
\end{tabular}




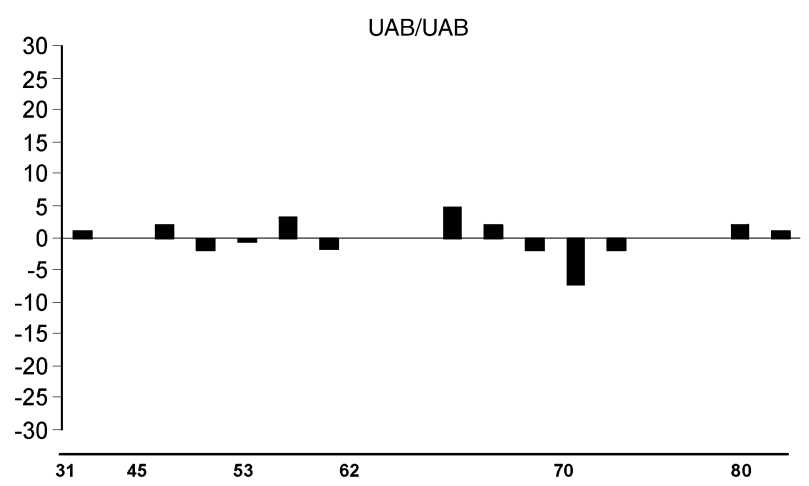

FIG. 3-Difference between the known and estimated ages-at-death for each specimen in the UAB collection, when the same collection is used as reference. See the text.

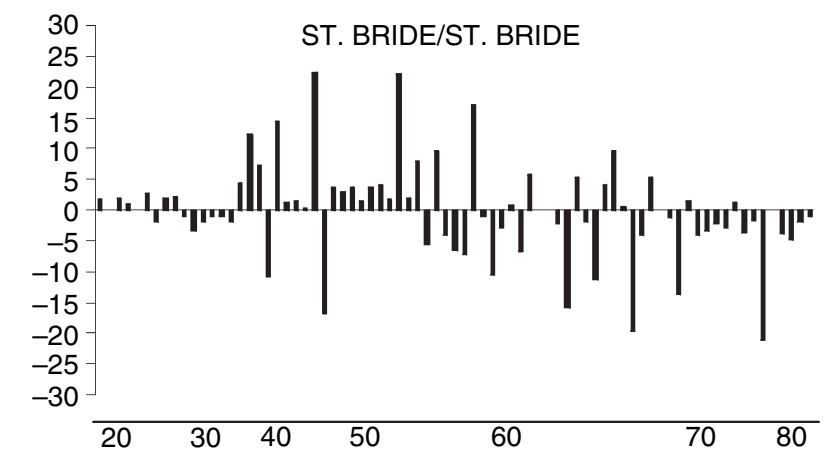

FIG. 4-Difference between the known and estimated ages-at-death for each specimen in the St. Bride collection, when the same collection is used as reference. See the text.

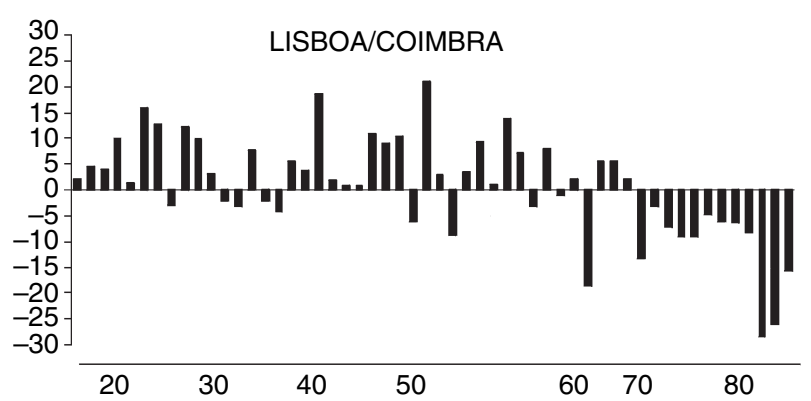

FIG. 5-Difference between the known and estimated ages-at-death for each specimen in the Lisbon collection, when the Coimbra collection is used as reference. See the text.

Coimbra, Lisbon and Barcelona as reference, $30 \%$ were within 5 years of the known age-at-death, 56\% within 10 years, $78 \%$ within 15 years, and $87 \%$ within 20 years. Among the results reported here, the most distant reference collection (Iberia estimating London) gave the least accurate estimates, even though the combined Iberian collections was the largest reference collection used.

Table 2 gives means and standard deviations for known age minus estimated age, using the four collections to estimate age in the seven different ways. To help reveal the nature of errors for specimens who lived long, who died young, or who died in middle age, for each way, mean and standard deviation are also given for the oldest half, the youngest half and the middle half of the test collection.

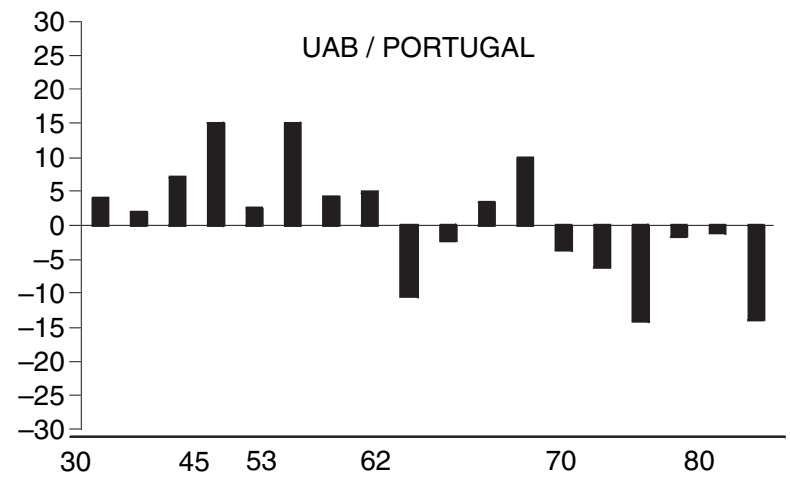

FIG. 6-Difference between the known and estimated ages-at-death for each specimen in the UAB collection, when Portuguese collections are used as reference. See the text.

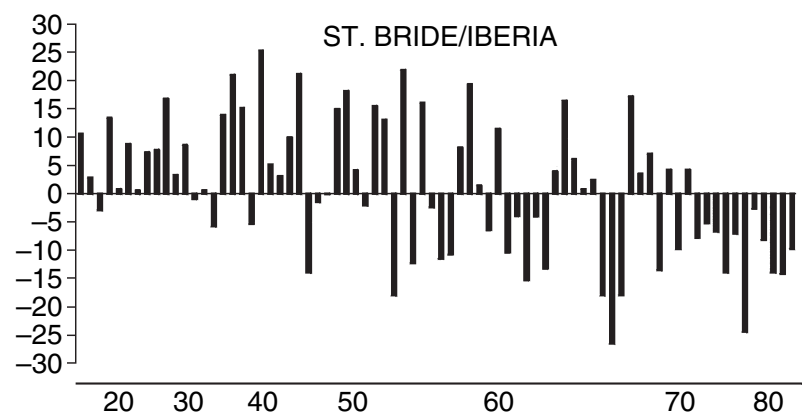

FIG. 7-Difference between the known and estimated ages-at-death for each specimen in the St. Bride collection, when Iberian collections are used as reference. See the text.

\section{Discussion}

Innominate bone is one of the most informative bones in the skeleton because, apart from secondary bones, it is formed by three independent elements (ilium, ischium and pubis) during the sub-adult life and it is directly involved with childbirth. These characteristics contribute with more information than bones normally supply (measurements, epiphysis fusion, and morphological alterations by muscles insertions or pathologies), furnishing us with supplementary information about sex and age in different stages of individual life. Furthermore now, it has also been well established that the acetabulum provides useful information to diagnose sex (27-29) and adult age $(17,18,30,31)$ of specimens of any age with fused acetabulum. This is very important because after death the acetabulum tends to remain well preserved (27), permitting us to observe and analyze features on this part of many skeletons.

The adult age estimation is one of the more difficult tasks undertaken in anthropology and forensic medicine. However, some morphological changes in the acetabulum that occur in adults were useful to estimate age of adult male specimens housed in the Anthropology Museum of the University of Coimbra (18). In this study, we use observations of the acetabulum to estimate ageat-death for specimens in three other collections. One immediate conclusion is to confirm the usefulness of the acetabulum as a basis for estimating age-at-death for adults from Mediterranean populations; this is consistent with the conclusions of RougéMaillard et al. $(30,31)$ and Rissech et al. $(17,18)$. Our results also demonstrate the utility of the acetabulum to estimate age-at-death for adults from an Anglo-Saxon population. 
TABLE 2-Means and standard deviations for known age-at-death minus estimated age-at-death, using four collections, Coimbra, Lisbon, UAB, and St. Bride, to estimate age-at-death in seven different ways, corresponding to the rows of the table.

\begin{tabular}{|c|c|c|c|c|c|c|c|c|c|}
\hline & \multirow[b]{2}{*}{$n$} & \multicolumn{2}{|c|}{ All } & \multicolumn{2}{|c|}{ Old half } & \multicolumn{2}{|c|}{ Young half } & \multicolumn{2}{|c|}{ Middle half } \\
\hline & & Mean & SD & Mean & SD & Mean & SD & Mean & SD \\
\hline Coimbra/Coimbra & 238 & $\begin{array}{c}0.04 \\
16-96 \text { a }\end{array}$ & 6.00 & $\begin{array}{l}-1.50 \\
43-96 \text { a }\end{array}$ & 6.53 & $\begin{array}{c}1.53 \\
16-43 \text { a }\end{array}$ & 4.92 & $\begin{array}{c}0.17 \\
30-58 \text { a }\end{array}$ & 5.87 \\
\hline Lisbon/Lisbon & 57 & $\begin{array}{c}0.43 \\
15-88 \text { a }\end{array}$ & 4.83 & $\begin{array}{l}-0.33 \\
54-58 \text { a }\end{array}$ & 5.26 & $\begin{array}{c}1.03 \\
15-53 \mathrm{a}\end{array}$ & 4.13 & $\begin{array}{c}0.08 \\
38-72 \text { a }\end{array}$ & 5.34 \\
\hline $\mathrm{UAB} / \mathrm{UAB}$ & 18 & $\begin{array}{c}0.02 \\
31-86 \text { a }\end{array}$ & 2.56 & $\begin{array}{l}-0.16 \\
63-86 \text { a }\end{array}$ & 3.08 & $\begin{array}{c}0.67 \\
31-62 \text { a }\end{array}$ & 2.03 & $\begin{array}{l}-0.32 \\
53-73 \text { a }\end{array}$ & 3.20 \\
\hline St. Bride/St. Bride & 77 & $\begin{array}{l}-0.21 \\
17-88 \text { a }\end{array}$ & 7.56 & $\begin{array}{l}-2.26 \\
58-88 \text { a }\end{array}$ & 7.38 & $\begin{array}{c}2.47 \\
17-56 \mathrm{a}\end{array}$ & 7.46 & $\begin{array}{c}0.89 \\
41-66 \text { a }\end{array}$ & 8.22 \\
\hline Lisbon/Coimbra & 54 & $\begin{array}{c}0.71 \\
15-88 \mathrm{a}\end{array}$ & 9.90 & $\begin{array}{l}-3.10 \\
54-88 \text { a }\end{array}$ & 11.00 & $\begin{array}{c}5.30 \\
15-53 \mathrm{a}\end{array}$ & 6.86 & $\begin{array}{c}3.55 \\
38-72 \text { a }\end{array}$ & 7.93 \\
\hline UAB/Portugal & 18 & $\begin{array}{c}0.99 \\
31-86 \text { a }\end{array}$ & 8.39 & $\begin{array}{l}-4.03 \\
63-86 \text { a }\end{array}$ & 7.19 & $\begin{array}{c}4.52 \\
31-62 \text { a. }\end{array}$ & 7.19 & $\begin{array}{c}1.35 \\
53-73 \mathrm{a}\end{array}$ & 7.29 \\
\hline St. Bride/Iberia & 76 & $\begin{array}{c}0.87 \\
17-88 \text { a }\end{array}$ & 11.83 & $\begin{array}{l}-4.37 \\
58-88 \text { a }\end{array}$ & 10.79 & $\begin{array}{c}5.71 \\
17-56 \mathrm{a}\end{array}$ & 10.46 & $\begin{array}{c}2.96 \\
41-66 \text { a }\end{array}$ & 12.03 \\
\hline
\end{tabular}

A pair of collections labels each row: test collection/reference collection $($ Portugal $=$ Lisbon + Coimbra, and Iberia $=$ Portugal $+\mathrm{UAB})$. To reveal the nature of errors for specimens, who lived long, who died young, or who died in middle age for each way, mean and standard deviation are also given for the young half, middle half and old half. Shown below each pair of statistics is the age range of specimens from which it was calculated.

When the rest of the collection to which a specimen belongs is used to calculate the estimating frequencies, age-at-death can be estimated with great accuracy. Although somewhat less accurate, estimates based on more distant reference collections are still reasonably accurate, even though there were more problems estimating age-at-death for British specimens with the further Iberian reference collections. Formerly, observations of the pubic symphysis (16) or of the auricular surface $(9,10)$ have been used to estimate age-atdeath for adults. Estimates reported here based on observations of the acetabulum are more accurate, even though the same Bayesian method was used in each case.

In all these estimates, there is a slight tendency to over estimate age for specimens that died young (between 15 and 20 years of age) and to under estimate age for specimens that lived to be over 70. However, the accuracy of these estimates does not vary much over the whole adult life span from 15 to 96. This differs from estimates based on measurements of the pubic symphysis or the auricular surface using the same estimating algorithm, whose accuracy dropped noticeably for specimens who lived more than 60 years, even though the estimates were made into only 10 year age intervals. These differences may result from the aging process acting differently in these different anatomical regions.

As was expected, there was a slight loss of accuracy when the reference collection was from a different place than the test specimens, with least accurate estimates made for specimens from St. Bride's Church London using the Iberian specimens as a reference collection. The Iberian specimens show very similar patterns of aging, which enables very good estimates of age-at-death within their own context. Although morphological changes during the aging process seem to be somewhat different between the English and the Iberian populations, we can generally consider their aging patterns similar.

Variability is an intrinsic characteristic of aging. Universal and progressive, it is the result of several genetic, cultural and environmental processes that take place at different rates in different individuals and populations. These processes determine the form and the extent of the morphological changes over time. Because these processes have been going on longer in individuals who live to be older than those who died younger, usually variability is greater among older specimens. Variability increasing with ages and the no lineal behavior in the trajectory of the aging process are the major source of difficulty in estimating age-at-death for adult specimens. Because of this, it is appropriate to use probabilistic methods to estimate age-at-death as a frequency distribution to more explicitly represent uncertainty in the estimate. Our results confirm what Lucy et al. (12), Schmitt and Broqua (14), Gowland and Chamberlain (15), Schmitt et al. (10), Schmitt (16), and Rissech et al. $(17,18)$ have earlier demonstrated; the Bayesian estimation methods employed here seem to provide an adequate tool for the estimation of age-at-death when used with a representative reference collection. Nevertheless, it seems necessary to accept a slight central bias at the extreme ends of the human life span. At the young and old end, bias results from the structural fact that the only possible errors are overestimation and under estimation respectively (Figs 1-7).

It is evident from our results that reference collections more typical of populations from which test specimens may have come give more accurate estimates. Some authors have proposed creating large reference collections based on large geographical areas, such as Europe, Africa or Asia, arguing that within these areas patterns of aging seem to be similar (10), but such reference collections from such large geographical areas require the use of wide age intervals and consequent loss of accuracy. Our results suggest that a more geographically restricted reference collection is more likely to represent the population to which test specimens belong, and thus more likely to provide more accurate estimates.

\section{Conclusion}

Our results show that observations of the fused acetabulum can be used to make accurate estimates of age-at-death for adults of any age in Western European populations, and that these estimations are generally more accurate than those based on observations of other areas of the innominate formerly used for this purpose. In addition, the acetabulum is especially useful because its relevant morphology tends to remain well preserved long after death. Thus, more studies of the acetabulum as an indicator of age-at-death should be made in order to understand better how this useful anatomical structure changes during the aging process in different populations. 


\section{Acknowledgments}

We want to thank Dr. Almaça, the Director of the Bocage Museum in Lisbon Portugal, and David Meara, the Cannon of St. Bride's Church in London U.K., for access to specimens.

\section{Grant Sponsorship}

Research grand (SFRH/BPD/6075/2001) from Fundação para Ciência e a Tecnologia-Operational Program Science Technology and Innovation (POCTI) to C Rissech.

This work was partially funded by MEC: CGL 200502567/BOS Spanish project.

\section{References}

1. Bocquet-Appel JP, Masset C. Farewell to the paleodemography. J Hum Evol 1982;12:321-33.

2. Saunders SR, Fitzgerald C, Rogers T, Dudar C, Mckillop H. A test of several methods of skeletal age estimation using a documented archaeological sample. Canadian Soc Foren Sci 1992;25:97-118.

3. Konigsberg LW, Frankenberg SR. Estimation of age structure in anthropological demography. Am J Phys Anthropol 1992;89:235-56.

4. Santos AL. How old is this pelvis? A comparison of age at death estimation using the auricular surface of the ilium and os pubis. In: Pwiti G, Soper RA, editors. Aspects of African archaeology. Procedings of the 10th Congress of the Pan African Association for Prehistory and related studies; 1995 Jun 18-23; Harare. Zimbabwe: Print Holdings, 1996;2936.

5. Bedford ME, Russel KF, Lovejoy CO, Meindl RS, Simpson SW, StuartMacadam PL. Test of the multifactorial aging method using skeletons with known ages-at-death from the Grant Collection. Amer J Phys Anthropol 1993;91:287-97.

6. Murray KA, Murray T. A test of the auricular surface aging technique. J Forensic Sci 1991;6(4):1162-9.

7. Boldsen JL, Milner GR, Konigsberg LW, Wood JW. Transition analysis: a new method for estimating age from skeletons. In: Hoppa RD, Vaupel J, editors. Paleodemography. Age distributions from skeletal samples. Cambridge: Cambridge University Press, 2002;73-106.

8. Kemkes-Grottenthaler A. Aging through the ages: historical perspectives on age indicators methods. In: Hoppa RD, Vaupel J, editors. Paleodemography. Age distributions from skeletal samples. Cambridge: Cambridge University Press, 2002;49-72.

9. Schmitt A. Variabilité de la sénescence du squelette humain. Réflexions sur les indicateurs de l'âge au décès: à la recherche d'un outil performant [Ph.D. dissertation]. Bordeaux: Universite de Bordeaux I, 2001.

10. Schmitt A, Murail P, Cunha E, Rougé D. Variability of the pattern of ageing on the human skeleton: evidence from bone indicators and implications on age at death estimation. J Forensic Sci 2002;47:348-476.

11. Rissech C, Schmitt A, Malgosa A, Cunha E. Influencia de las patologías en los indicadores de edad adulta del coxal: estudio preliminar. Antropologia Portuguesa 2003/2004;20/21:267-79.

12. Lucy D, Aykroyd RG, Pollard AM, Solheim T. A Bayesian Approach to adult human age estimation from dental observations by Johanson's age changes. J Forensic Sci 1996;41:189-94.

13. Hoppa RD, Vaupel JW. The Rostock manifesto for paleodemography: the way from stage to age. In: Hoppa RD, Vaupel J, editors. Paleodemography. Age distributions from skeletal samples. Cambridge: Cambridge University Press, 2002;1-8.
14. Schmitt A, Broqua C. Approche probabilistite pour estimer l'âge au décès a partir de la surface auriculare de l'ilium. Bull Mém Soc Anthropol París 2000;5:293-300.

15. Gowland RL, Chamberlain AT. A Bayesian approach to ageing perinatal skeletal material from archaeological sites: implications for the evidence for infanticide in Roman-Britain. J Archaeol Sci 2002;29:677-85.

16. Schmitt A. Age-at-death assessment using the os pubis and the auricular surface of the ilium: a test on an identified Asian sample. Int J Osteoarchaeol 2004;14:1-16.

17. Rissech C, Schmitt A, Cunha E, Malgosa A. Estimación de la edad adulta masculina a través del acetábulo. In: Egocheaga JE, Sierra MJ, editors. Biología de las poblaciones humanas: diversidad, tiempo, espacio. Oviedo: Universidad de Oviedo, 2004.

18. Rissech C, Estabrook GF, Cunha E, Malgosa A. Using the acetabulum to estimate age at death of adult males. J Forensic Sci 2006;51:213-29.

19. Rocha MA. Les collections ostéologiques humaines identifiées du Musseé Anthropologique de l'Université de Coimbra. Antropologia Portuguesa 1995;13:17-38.

20. Cardoso H. Brief communication: the collection of identified human skeletons housed at the Bocage Museum (National Museum of Natural History), Lisbon, Portugal. Amer J Phys Anthropol 2006;129:173-6.

21. Safont S, Malgosa A, Subira E. Sex assessment on the basis of long bone circumference. Amer J Phys Anthropol 2000;113:317-28.

22. Rissech C, Sañudo JR, Malgosa A. The acetabular point: a morphological and ontogenetic study. J Anat 2001;198:743-8.

23. Black SM, Scheuer JL. A multidisciplinary approach to osteological research. J Paleopathol 1995;7:78.

24. Black SM, Scheuer JL. Occipitalisation of the atlas with reference to its embryological development. Int J Osteoarchaeol 1996;6:189-94.

25. Cunha E. Osteoarthritis as an indicator of demographic structure of past populations: the example of a Portuguese medieval sample. In: Perez-Perez A, editor. Salud, enfermedad y muerte en el pasado. Consecuencias biologicas del estrés y la patología. Barcelona: Fundación Uriach 1838, 1996;149-55.

26. Efron B. The jacknife, the bootstrap, and other resampling plans. Philadelphia: Society for Industrial and Applied Mathematics, 1982.

27. Rissech C, Malgosa A. Sex prediction by discriminant function with central portion measures of innominate bones. Homo 1997;48(1): 22-32.

28. Rissech C, García MM, Malgosa A. Sex and age diagnosis by ischium morphometric analysis. Forensic Sci Int 2003;135:188-96.

29. Rissech C, Malgosa A. Ilium growth study: applicability in sex and age diagnosis. Forensic Sci Int 2005;147:165-74.

30. Rougé-Maillart $\mathrm{Cl}$, Telmon N, Rissech C, Malgosa A, Rougé D. The determination of male adult age by central and posterior coxal analysis. A preliminary study. J Forensic Sci 2004;49:1-17.

31. Rougé-Maillart C. Estimation de l'âge à partir de la partie postérieure du bassin: étude comparée de la surface auriculaire et du cotyle [diplôme d'étude approfondie d'Anthropologie dissertation]. Toulouse: Université de Toulouse le Mirail, 2000.

Additional information and reprint requests:

Carme Rissech, M.D., Ph.D.

Unitat d'Antropologia Biològica

Departament de Biologia Animal, Vegetal i Ecologia

Facultat de Ciències

Universitat Autònoma de Barcelona

08193 Bellaterra

Spain

E-mail: Carme.Rissech@uab.es 